\title{
58- Investigation of contemporary instruction modes in EFL teaching: blended learning \& flipped classroom
}

Zafer ÜSTÜNBAŞ1

Ömer Faruk İPEK²

APA: Üstünbaş, Z.; İpek, Ö. F. (2021). Investigation of contemporary instruction modes in EFL teaching: blended learning \& flipped classroom. RumeliDE Dil ve Edebiyat Araşttrmaları Dergisi, (25), 987-998. DOI: 10.2900o/rumelide.1037414.

\begin{abstract}
Teaching English as a Foreign Language (EFL) has undergone theoretical and practical changes during decades depending on the conditions of the era. Changing circumstances have caused different approaches to emerge. With the introduction of the internet into social life and the area of education, different technological infrastructures have been created and put into practice in schools. While IT (Information Technology) once was only taught as a course at schools, even the courses themselves are now being provided through the Internet and the technological infrastructures it presents. Technological advances in recent decades have modernized EFL teaching accordingly. Technology has been benefited to assist the teaching and learning process and specially to deliver the information in different modes. As a more recent development, with widely implemented distance education after the COVID-19 pandemic broke out in the beginning of 2020, which affected the whole education system and settings, the need for emphasizing and investigating contemporary educational models and approaches for EFL classes has become a necessity. Therefore, in this conceptual study, we aimed to discuss blended learning and flipped classroom theoretically as contemporary approaches that are used in EFL classrooms. Specifically, we discussed the hegemony of technology, blended learning and flipped classroom in English language classrooms by investigating the recent studies and the literature on these concepts. The literature has revealed that these contemporary instruction modes which have increasingly been investigated are highly advantageous and useful for both teachers and students. In this conceptual study, it has been concluded that blended learning and flipped classroom are effective in increasing students' academic performances and motivation. It has also been found that they can lead students to have positive attitudes towards learning English.
\end{abstract}

Keywords: blended learning, EFL, flipped classroom, instruction modes

\section{Yabancı dil olarak İngilizce öğretiminde çağdaş öğretim türleri: harmanlanmış öğrenme \& ters-yüz sınıf}

\section{$\ddot{O} z$}

Yabancı Dil Olarak İngilizce Öğretimi (EFL), çağın koşullarına bağlı olarak on yıllar boyunca teorik ve pratik değişikliklere uğramıştır. Değişen koşullar farklı yaklaşımların ortaya çıkmasına neden olmuştur. İnternetin sosyal hayata ve eğitim alanına girmesiyle okullarda farklı teknolojik altyapılar oluşturulmuş ve uygulamaya konulmuştur. BT (Bilgi Teknolojileri) bir zamanlar sadece okullarda

Öğr. Gör., Bolu Abant İzzet Baysal Üniversitesi, Yabancı Diller Yüksekokulu, İngilizce Hazırlık Bölümü (Bolu, Türkiye), zaferustunbas@gmail.com, ORCID ID: 0000-0003-2687-4892 [Araştırma makalesi, Makale kayıt tarihi: 05.09.2021kabul tarihi: 20.10.2021; DOI: 10.29000/rumelide.1037414]

Dr. Öğr. Üyesi, Bolu Abant İzzet Baysal Üniversitesi, Yabancı Diller Yüksekokulu, İngilizce Hazırlık Bölümü (Bolu, Türkiye), theipekk@gmail.com, ORCID ID: oooo-0003-1921-3332 
ders olarak okutulsa da, günümüzde derslerin kendileri bile artık internet ve sunduğu teknolojik altyapılar aracılığıyla sağlanmaktadır. Son yıllardaki teknolojik gelişmeler Yabancı Dil Olarak İngilizce Öğretimini bu doğrultuda modern hale getirmiştir. Öğretim ve öğrenme sürecine yardımcı olmak ve özellikle bilgileri farklı modlarda sunmak için teknolojiden yararlanılmıştır. Daha yakın bir gelişme olarak, 2020'nin başında ortaya çıkan ve tüm eğitim sistemini ve uygulamalarını etkileyen COVID-19 salgını sonrasında uzaktan eğitimin yaygın olarak uygulanması ile EFL sınıflarında çağdaş eğitim modellerinin ve yaklaşımlarının öneminin vurgulanması ve araştırılması ihtiyacı bir gereklilik haline gelmiştir. Bu nedenle bu kavramsal çalışmada, EFL sınıflarında kullanılan çağdaş yaklaşımlar olan harmanlanmış öğrenme ve ters-yüz sınıf modellerini teorik olarak tartışmayı amaçladık. Özellikle yakın zamandaki çalışmaları ve bu kavramlarla ilgili literatürü araştırarak İngilizce sınıflarındaki teknoloji hegemonyasını, harmanlanmış öğrenme ve ters-yüz sınıf modellerini tartıştık. Alanyazın, giderek daha fazla araştırılan bu çağdaş öğretim türlerinin hem öğretmenler hem de öğrenciler için son derece faydalı ve kullanışlı olduğunu ortaya koymaktadır. Bu kavramsal çalışmada harmanlanmış öğrenme ve ters-yüz sınıf modellerinin öğrencilerin akademik performanslarını ve motivasyonlarını artırmada etkili oldukları sonucuna varılmıştır. Ayrıca öğrencilerin İngilizce öğrenmeye karşı olumlu tutumlar sergilemelerine yol açabilecekleri görülmüştür.

Anahtar kelimeler: harmanlanmış öğrenme, Yabancı Dil Olarak İngilizce, ters-yüz sınıf, öğretim türleri

\section{Introduction}

Many approaches and methods have been utilized in English Language Teaching (ELT) so far with the changing opportunities and requirements of the decades. The focus, for instance, was to teach English as quick as possible with frequent mechanical drills in Audio Lingual Method (ALM) in the beginning of the 2oth century, which was based on the behaviorist theory. ALM, which is known as one of the preceding methods in ELT, was a popular approach then due to the requirements and opportunities of the era. That behaviorist and mechanical approach was replaced by communicative and studentcentered ones in time towards the end of the $20^{\text {th }}$ century. Communicative language teaching, which focused on learning in cooperation, utilization of technological tools etc., was the overwhelming approach in language pedagogy (Pardede, 2020). Students have become the center of foreign language classes, and classes have been transformed into more communicative enabling frequent student interactions. Fast-growing technology has also brought concomitant developments to language teaching such as contemporary methods and new educational tools. The term of information and communication technology (ICT) has become important for language teaching. In general, ICTs have brought about profound changes in the education system (Paudel, 2021). ICT tools have been remarkably integrated with language classes, especially in the ELT classes in the 21st century.

In particular, from the beginning of 2020, all instructional designs of education have been affected. In an education system that has evolved from traditional face-to-face education to distance education applications where technology infrastructure is used, the integration of technology into schools and the realization of theoretical and practical information and data related to this are very important. In order to make English teaching effective and target-oriented, and to combine the latest opportunities and necessities of the era with language teaching, contemporary approaches must be implemented in teaching English. For this reason, upon the importance of it, taking all above-mentioned ideas into consideration, this article will present relevant information about contemporary approaches used in EFL 
teaching such as blended learning and flipped classroom, which needs to be emphasized particularly in this technology era.

\section{The hegemony of technology in EFL classes}

The integration of technology which has basically started with computers, overhead projectors, television, videocassettes has continued with the Internet, interactive white boards, projections, audiobooks, online educational tools, smartphones etc. Like in every field, technology has become indispensable for language teaching and learning due to its positive effects for every stakeholder of education ranging from teachers to parents and contemporary concerns. The integration of ICT tools into language classes has become inevitable since learners have turned into a '...frequent technology users starting from a very early age" (Papadima-Sophocleous, Gianniskas \& Kakoulli-Constantinou, 2014, p. 297) In time, learning habits and learners' attitudes of learning English have undergone changes as a result of the changed learner traits. Since the new generation of learners are digital natives, it requires language teachers to make the best use of ICT in language classes (Bijeikienè, Ratinskienè \& Zutkiené, 2011). As Hol and Aydın (2020) puts it, "computer games, emails, the Internet, cell phones and instant messaging services have become an essential part of their lives" (p. 39). In this context, disregarding technology in language classes will be an outdated attitude and against the digital natives. According to Tucker (2012), today's skills and knowledge which need to be mastered differ from those of decades ago, maybe even from a close date. She has also added that teaching these skills to learners becomes easier with the integration of technology by teachers, which allows learners to collaborate and cooperate. Thereby, utilization of technology in education and EFL classes indeed has become critically important.

The development of ICT and increasing need for the integration of it in language classes has brought along some other changes in certain areas such as teaching methods, access to the information, learners' study habits etc. These changes have led way to different contemporary approaches to conceptualize such as computer-assisted language learning (CALL), blended learning (BL), flipped classroom (FC), online learning, mobile-assisted language learning (MALL), which have widely been used in teaching English so far. These contemporary methods have been utilized actively in many areas ranging from business to education, but their use in language teaching is of utmost importance. Especially, blended learning and flipped classroom are significant concepts for EFL area as being directly linked to teaching and learning. It is obvious that these disciplines are employed widely by EFL teachers in English classes all around the world, and they have had positive effects on language teaching.

\section{Defining and reviewing blended learning approach}

Blended learning is a contemporary approach to teaching and learning which basically corresponds to combining technology and traditional practices of education. There is no compromised definition of it as the scholars have approached this term with various perspectives and used different terms for the definition. Broadly, Graham (2006) defines it as combining '...face-to-face instruction with computermediated instruction" (p. 5). Graham discusses this term with historical approach, asserting that these are two historically distinct types of teaching and learning. According to Whitelock and Jelfs (2003, as cited in Oliver \& Trigwell, 2005), blended learning is "the integrated combination of traditional learning with web-based online approaches" (p. 17), which is a broad interpretation. Another definition of BL is by Leakey and Ranchoux (2006) defining it as; 
Blended learning in CALL is the adaptation in a local context of previous CALL and non-CALL pedagogies into an integrated program of language teaching and learning drawing on different mixes of media and delivery to produce an optimum mix that addresses the unique needs and demands of that context. (p.358)

What meant by "non-CALL pedagogies" in the definition above points to the practices of traditional teaching in which CALL approach is not benefited. In other words, the definition refers to integrating CALL-based technology into traditional teaching. Also, Tucker (2012) has described blended learning as the integration of face-to-face education with online teaching. On the other hand, Sharma (2010) has approached this concept with a broader perspective defining as combining face-to-face education with "appropriate use of technology" (Sharma \& Barret, 2007, p. 7, as cited in Sharma, 2010, p. 457). Restricting the use of technology into only online resources excludes other tools related to computers, which, in turn, narrows down the concept of blending into only one form. However, blended learning could include both online and offline applications. BL is also interpreted as combining e-learning with traditional education. Oliver and Trigwell (2005) evaluates the term 'e-learning' as too broad and unclear since anything could be included in that. Littlejohn and Pegler (2007) have defined e-learning as "the process of learning and teaching using computers and other associated technologies, particularly through use of the internet" (p. 17). Drawing upon this explanation, it could be said that e-learning focuses on using computer-related technologies in learning and teaching. Therefore, blended learning could broadly be defined as integrating web-based ICT with face-to-face education. Nakayama, Mutsuura and Yamamoto (2016) have given a similar description stating '....blended learning, which consists of face-to-face sessions and learning materials that are supported by information communication technologies (ICT)...” (p. 43). BL can be illustrated as adding any forms of dairy products such as milk, powder, cream etc. into the cup of coffee. The coffee itself represents face-to-face education, and the topping-up accounts for ICT tools. What is produced at the end as 'milk coffee' could be envisioned as blended learning. (see figure 1 for a sample illustration of blended learning).

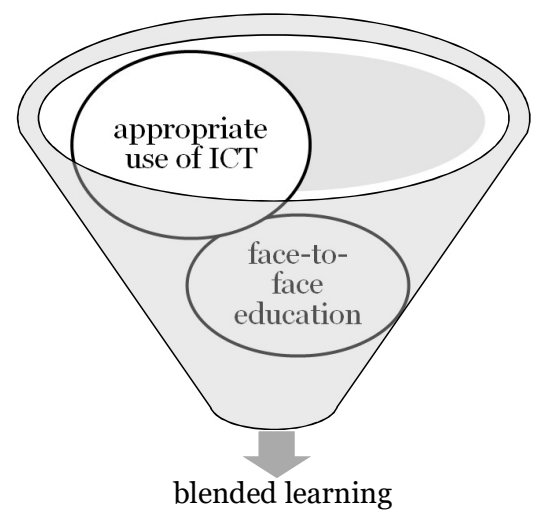

Figure 1. Sample illustration of blended learning

The related literature shows that blended learning has various definitions, and there is no consensus on it. Driscoll (2002) has mentioned about this ambiguity stating that '...blended learning means different things to different people" (p. 1). However, it could be referred that majority of the definitions include the use of computer and similar technologies with face-to-face education. Blended learning mode includes online and offline delivery of information. Although there are slight differences between the current definitions of blended learning, what really matters is its implementation, outcomes, and perceptions in teaching English. 
Especially in the $21^{\text {st }}$ century, being exposed to authentic materials has become critical for the acquisition of language skills. Prior to the technology era and contemporary approaches in ELT world, the chance to find various authentic materials or deliver the course content in different modes was limited. The process of teaching and learning mostly took place only at schools as opposed to today. Contrary to blended learning or computer-assisted language learning, traditional face-to-face classes limit the learners' opportunities to learn in self-regulated or individualized ways. Teaching in these classes was performed in only one way in which the teacher presented the course content in front of the classroom, and the stages of teaching such as presentation, practice and production were tried to be performed during the class times without or with only little assistance of ICT. However, blended learning has diversified the modes of delivering and accessing to information in time. Students have started having the opportunity to study or practice the course content out of the class as well by means of personalized computers at home. Also, teaching has sometimes been moved from the during-class stage to the prior class through online platforms, which is another teaching mode that will be discussed later. Learning environment has changed remarkably from past to present, and it will continue changing for better in the future. Graham (2006) illustrates this change in teaching modes with a well-explained diagram. (see figure 2 for the above-mentioned illustration for the transformation in teaching modes historically.

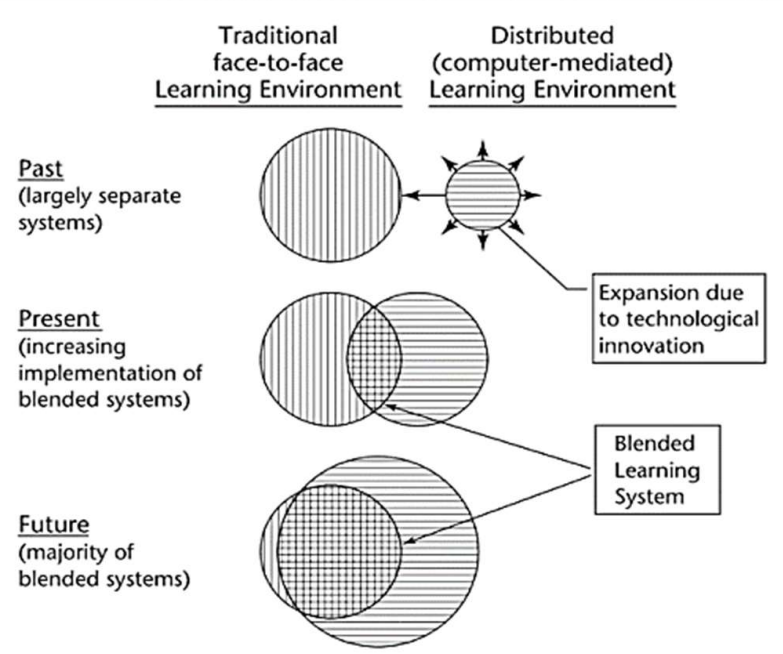

Figure 2. Graham's (2006) interpretation of the change in blended learning system over time (p. 6).

As seen in the figure, although there have been technological advances in time, their integration into face-to-face education have not happened immediately. The diagram shows that what we have at present is a well-balanced integration of face-to-face and computer-assisted education. In the future, ICT will probably take a considerable part of the classes, which means that blended learning will be a critical approach, especially for teaching or learning a foreign language because of global and language issues. Blended learning will perhaps be a standard approach in the future, and we will quit using the term blended exclusively (Cleveland-Innes \& Wilton, 2018).

\section{Implementation of blended learning in EFL teaching}

Blended learning is a beneficial and an advantageous method especially for language teaching. It provides benefits for both teachers and learners. As it is a popular contemporary approach in language teaching, researchers have put emphasis on investigating the effectiveness of it in teaching and learning 
and learners' perceptions/attitudes towards it. As for EFL teaching, there have been various studies in the literature investigating the use of blended learning in teaching of the language skills and sub-skills (eg., for listening: Caruso, Colombi \& Tebbit, 2017; Tran \& Ma, 2021; for speaking: Wang, 2020; for reading: Bataineh \& Mayyas, 2017; for writing: Challob, Bakar \& Latif, 2016; for grammar: Al-Bataineh, Banikalef \& Albashtawi, 2019; for vocabulary: Ebadi \& Ghuchi, 2018). Majority of the studies have resulted that blended learning has positive effects on learners' performances in the related skills. Besides, researchers have also investigated the perceptions or attitudes of learners who have had an experience in blended learning (eg., Al-Bataineh, Banikalef \& Albashtawi, 2019; Ebadi \& Ghuchi, 2018; Erdem \& Kibar, 2014; İstifci, 2017; Rianto, 2020; Wang, Chen, Tai \& Zhang, 2019). It has also emerged in these studies that the learners have positive attitudes towards blended learning. They have found blended learning experience useful and practical.

In the study conducted by Caruso et al. (2017), the researchers have investigated the effects of blended learning on the learners' listening skill in Italian. Instead of face-to-face mode, the students had online listening quizzes in which they could have the chance to do the tasks in quizzes through multiple access enabling them to study in a flexible way. Majority of the students have found these online quizzes fun, motivating and practical. They reported in the study that they have liked the idea of being able to listen to the tracks more than once. Most of them completed the tasks, and they reported that online quizzes helped them improve their listening skill and proficiency in Italian. In another study, Tran \& Ma (2021) have investigated the students' perceptions towards the effects of online formative assessment in listening on their related skills. The study took place at a Vietnamese university, and the study group comprised of 60 students whose major was English. According to the results of the questionnaire and interviews, online learning provided the participants with a valuable experience with varied online sources and offered an adaptable and individualized learning. It also emerged that it provided the students with opportunities to practice their listening skill effectively. In general, these studies show that the Internet, which is an ICT tool, is a good source for delivery of information for listening skill in English especially because of providing authenticity, individualized learning, flexibility, variety, time and cost saving.

In another study, Wang (2020) conducted an experimental study to investigate the effects on blended learning on Taiwanese students' speaking skill in English. 136 participants were divided into three groups according to their proficiency level depending on the placement test. Along with the face-to-face classes, the participants needed to take 12 online conversation courses which they could attend autonomously and in a flexible way. Although there was no control group, post-test scores showed that online classes considerably increased the students' conversational skill as assessed by three experienced instructors. As for reading skill, Bataineh and Mayyas (2017) performed a study to investigate the effects of teaching through blended learning with Moodle system. The results of the quasi-experimental study showed that the experimental group having blended mode of instruction through Moodle system outperformed those in control group with only face-to-face instruction in reading techniques such as scanning, skimming etc.. As for writing skill, Challob et al., (2016) have conducted a qualitative study on the use of BL in collaborative writing in EFL. 12 participants took part in the study. Apart from faceto-face instruction, they also had online instruction in class blog and discussion panel for 13 weeks. BL was reported to have helped to reduce the participants writing anxiety and increased their writing performances.

The implementation of blended mode of instruction in teaching English bears importance for both EFL teachers and learners. The Internet especially offers a wide variety of options in delivering the 
instruction and supporting teaching and learning. Students can be assessed, assigned, supported online in blended learning. Besides, computers or related technology could also be utilized during the class in face-to-face mode of instruction. ICT tools could be benefited during the class. For instance, Web 2.0 and mobile language applications are useful tools to assist language skills, and they have been widely used in EFL classes so far. Studies have found that they have positive effects on teaching/learning English (eg., Chaikovska \& Zbaravska, 2020; Gharehblagh \& Nasri, 2020; Ghorbani \& Ebadi, 2020; Korkmaz \& Öz, 2021; Osifo, 2019; Sato, Murase \& Burden, 2020). Especially, mobile-assisted language learning enables students to work individually at their own pace, and collaboratively with their peers. They could also be used as a warm-up and icebreakers in that they help to motivate and engage students.

In fact, blended learning is an umbrella term which includes different types of teaching or implementations one of which is flipped classroom. It is also a common and effective method in EFL teaching. In the next part, flipped classroom will be discussed.

\section{The ratio behind flipped classroom}

Flipped classroom, which is a modern and popular method in education, is a version of blended learning. It is basically defined as "that which is traditionally done in class is now done at home, and that which is traditionally done as homework is now completed in class" (Bergmann \& Sams, 2012, p. 13). It is simply described as "school work at home and homework at school" (Flipped Learning Network, 2014). In a traditional face-to-face class, students are taught and instructed in the classroom, and they are assigned for practice at home. However, in flipped classroom model, which is also known as 'inverted classroom' (İyitoğlu \& Erişen, 2017), the teaching is flipped by moving the teaching stage from duringclass into prior-class and moving practice from after-class into during-class stage, so students and teachers function reversely in a flipped classroom. Contrary to a traditional classroom, students have the instructions about the subject matter which is presented via an online platform in different forms such as presentations, videos, audios etc. Class time is allocated for practice, consolidation, interactions, group works, collaboration, which all require students' active engagement in learning. Flipped classroom also enables students to get an individualized education suitable for their individual needs (Bergmann \& Sams, 2012) as they study the course content at their own pace at home before the class. Also, the variety of flipped resources in forms of presentations, audios, videos, websites, articles enable students to have appropriate contents that suit their own type of intelligence. Although flipped learning simply accounts for inverted way of teaching, there are important factors for a classroom to be flipped. Flipped Learning Network (2014) have explained these important components of flipped classroom by dividing it into four pillars as follows:

$$
\begin{aligned}
& \text { F - Flexible Environment } \\
& \text { L - Learning Culture } \\
& \text { I - Intentional Content } \\
& \text { P - Professional Educators }
\end{aligned}
$$

As could be seen from the anagram, flipped classroom is not only a simple and coincidental practice; instead, it is a systematic approach. Another interpretation of the term has been presented by Alsowat (2016) explaining the important components of flipped classroom as: (1) cooperation, (2) student- 
centeredness, (3) elaborated learning environments, (4) time for preparation and (5) administrative support. These factors lead to a precise flipped classroom experience to emerge.

Flipped classroom is a widespread method used in foreign language teaching with a view to its advantages and positive effects for both teachers and students. The idea of flipping was brought up by two teachers named Jonathon Bergmann and Aaron Sams who first started to record their Chemistry classes for absent students to keep up with, and they uploaded these recordings to a website after the class. Then they came up with the idea of flipping the classroom by delivering the instruction to the students prior to the class, thus, allocating more time to facilitate, guide and support them during the class. This idea was also favored by the students. Since then, flipped classroom has been a practical and useful method to be used in all subjects in education.

One of the areas that draw on flipped classroom considerably is EFL teaching. As it is a contemporary and useful method, and it also has important advantages, EFL teachers utilize it in English classes. As learning a foreign language is challenging and demanding in terms of effort and time, flipped classroom stands out as a gap-filling solution for teaching/learning process. Researchers have conducted studies on the use of flipped classroom in EFL teaching, and they have addressed a number of advantages and recommendations, which will be discussed in the next part.

\section{Examining and analyzing research on the implementation of flipped classroom in EFL}

As English is a lingua franca, which accounts for "any lingual medium of communication between people of different mother tongues" (Samarin, 1987, p. 371), the necessity of speaking it has gained more importance day by day. Knowing English has turned out to have survival importance especially for teenagers who spend a plenty of time with their technological gadgets and the Net (İyitoğlu \& Erişen, 2017). The number of speakers of English as a foreign language has increased in the $21^{\text {st }}$ century along with the changing world and developing technology. Computers, the Internet, smartphones, and tablet computers have made it easier to access and be exposed to English at home. Apart from this, as the world population increases, classrooms have become more crowded. Under this condition, it becomes challenging for English teachers to teach to a crowded class, interact with each student. It is hard to allocate enough time for presenting information, practice, production during a face-to-face class at schools. Introducing the subject matter covers a plenty of time during a class hour and does not leave enough time for practice, interaction, discussion etc. Also, teaching of language skills of English necessities various methods, techniques and implementations, which could all need time. Taking these concerns into consideration, adopting a flipped classroom method can facilitate abovementioned drawbacks in English language teaching.

One of the areas in which flipped classroom has been widely employed is EFL teaching. As English is the most-widely spoken foreign language in the world, teaching this language requires EFL teachers and curriculum planners to have bonds with international community and track the latest developments in terms of teaching methodology. In this context, flipped classroom stands as a contemporary and advantageous method for teaching English. It has been implemented in listening, speaking, reading and writing, grammar and vocabulary classes, and it has positively affected the students' language performances and perceptions. There are a number of studies having been conducted by the researchers on the use of flipped classroom in EFL context in the literature. 
As for reading skill, Abaeinan and Samadi (2016) conducted a study on the effects of flipped instruction on students' reading performances. They divided the participants into two groups as experimental and control groups, and the former received a 10-week flipped instruction through video lectures on reading techniques. At the end of the treatment, the flipped group were seen to outperform those in control groups in using comprehension techniques and participating the class discussions. On the other hand, Al-Naabi and Alshrumaimeri (2020) performed a quasi-experimental study to investigate the effects of flipped grammar instruction that was delivered through videos in Edmodo on the students' grammar performances. The results indicated that the experimental group with flipped instruction performed better in post-test than those in control group. The students were also seen to have positive attitudes towards flipped classroom experience. As for listening skill, Etemadfar, Soozandehvar and Namaziandost (2020) conducted a quasi-experimental study with 40 participants on the related skill. The students in the experimental group were exposed to audios and videos prior to the class, and they were asked to discuss about the topic with their group mates. As they came to the class with a preparation, they performed better in the listening comprehension questions in the classroom. The results showed a significant difference between the scores of experimental and control groups as in favor of the former. Ekmekçi (2017), on the other hand, performed a quasi-experimental study on the relationship between flipped classroom model and the students' performances on writing skill. In the study, the experimental group got flipped instruction on writing different types of paragraphs through Edmodo for fifteen weeks. The results of the study showed that the flipped group performed better in composing paragraphs and in-class tasks when compared to those in non-flipped groups. Another study conducted by Wu, Hsieh and Yang (2017) showed that flipped instruction in speaking enhanced the students' performances on storytelling, class discussion, group works in flipped group remarkably. Overall, flipped classroom provides a variety of advantages for EFL teaching although having a few possible drawbacks (see table 1) as follows:

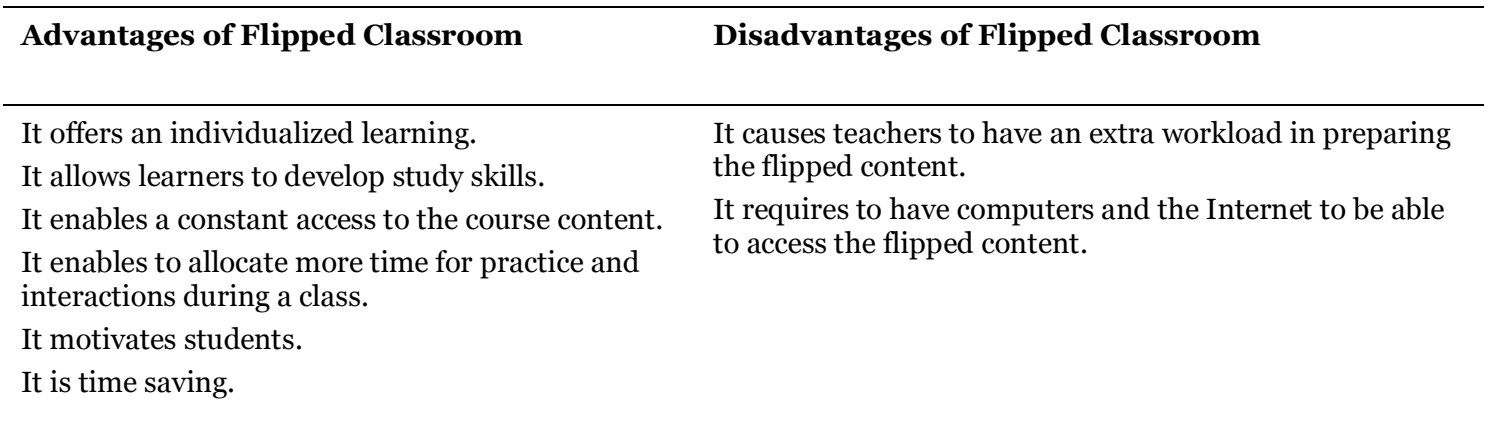

Table 1. Advantages and disadvantages of flipped classroom

Overall studies above indicate that flipped classroom has been found an effective method to enhance the students' academic performances and in skills of English. Flipped learning also helps EFL learners develop study skills, learning strategies, autonomy, and critical thinking.

\section{Conclusion}

Contemporary conditions have led to radical changes in teaching. With the effect of developing technology, the integration of ICT tools into traditional classes has become inevitable. Like in every field, computers and related technology have considerably changed teaching methods by leading to modern approaches to come out since they first appeared. The approaches such as blended learning, flipped 
classroom have diversified the ways of delivering the information with the integration of online mode, which, in turn, has brought considerable advantages to teaching. Teachers have benefited these contemporary approaches, especially in EFL teaching since they are appropriate methods for teaching a foreign language.

English is a widely spoken foreign language which is taught to millions of learners in all stages of formal education all over the world. In this respect, teaching of it requires competency and careful planning. EFL teachers and curriculum planners must know about the latest developments regarding EFL teaching in the world. The increase in the world population and the demand for learning English has led to crowded classes, which is a barrier for effective teaching. This situation also decreases the frequency and efficiency of class interactions such as pair-work, group work etc. that are important components of communicative language learning. Apart from crowded classes, limited class hours are another obstacle for a comprehensive teaching. Therefore, these factors have necessitated the integration of web-based technology that enables the online distribution of information as well. Class hours can be utilized through web-based approaches such as blended learning and flipped classroom.

Taking all of these into consideration, this article has presented information about popular technological implementations in EFL classes. As the literature shows, blended learning and flipped classroom have been utilized increasingly by EFL teachers all around the world, and a great number of studies have been conducted by the researchers in this field. It could be seen that the implementation of these contemporary approaches provides many advantages for EFL teaching in that they increase the students' academic performances, motivation and attitudes. It can also be inferred that they provide practicality with regard to time and use. In this respect, blended learning and flipped classroom could be integrated into curriculums by curriculum planners, and EFL teachers could adopt these approaches for their classrooms. Also, teachers could attend in-service trainings about blended learning and flipped classroom to be informed about the applications and apply them into their classes. School administrators should support teachers morally and materially to adopt contemporary approaches. Besides, there could be more studies on the latest developments in EFL teaching, their implementations and students' performances.

\section{Rerefences}

Abaeian, H., \& Samadi, L. (2016). The effect of flipped classroom on Iranian EFL learners' L2 reading comprehension: Focusing on different proficiency levels. Journal of Applied Linguistics and Language Research, 3(6), 295-304.

Al Bataineh, K. B., Banikalef, A., \& H Albashtawi, A. (2019). The effect of blended learning on EFL students' grammar performance and attitudes: an investigation of Moodle. Arab World English Journal (AWEJ) Volume, 10.

Al-Naabi, I. S. (2020). Is It Worth Flipping? The Impact of Flipped Classroom on EFL Students' Grammar. English Language Teaching, 13(6), 64-75.

Alsowat, H. (2016). An EFL flipped classroom teaching model: Effects on English language higher-order thinking skills, student engagement and satisfaction. Journal of Education and Practice, 7(9), 108-121.

Bataineh, R. F., \& Mayyas, M. B. (2017). The utility of blended learning in EFL reading and grammar: A case for Moodle. Teaching English with Technology, 17(3), 35-49.

Bergmann, J., \& Sams, A. (2012). Flip your classroom: Reach every student in every class every day. International society for technology in education. 
Bijeikienè, V., Raținskienè, S., \& Zutkienè, L. (2011). Teachers' attitudes towards the use of blended learning in general English classroom. Studies about languages, (18), 122-127.

Caruso, M., Gadd Colombi, A., \& Tebbit, S. (2017). Teaching how to listen. Blended learning for the development and assessment of listening skills in a second language. Journal of University Teaching \& Learning Practice, 14(1), 14.

Challob, A. A. I., Bakar, N. A., \& Latif, H. (2016). Collaborative Blended Learning Writing Environment: Effects on EFL Students' Writing Apprehension and Writing Performance. English Language Teaching, 9(6), 229-241.

Chaikovska, O., \& Zbaravska, L. (2020). The efficiency of Quizlet-based EFL vocabulary learning in preparing undergraduates for state English exam. Advanced education, 84-90.

Cleveland-Innes, M., \& Wilton, D. (2018). Guide to blended learning.

Driscoll, M. (2002). Blended learning: Let's get beyond the hype. E-learning, 1(4), 1-4.

Ebadi, S., \& Ghuchi, K. D. (2018). Investigating the Effects of Blended Learning Approach on Vocabulary Enhancement from EFL Learners' Perspectives. Journal on English Language Teaching, 8(2), 57-68.

Ekmekci, E. (2017). The flipped writing classroom in Turkish EFL context: A comparative study on a new model. Turkish Online Journal of Distance Education, 18(2), 151-167.

Erdem, M., \& Kibar, P. N. (2014). Students' Opinions on Facebook Supported Blended Learning Environment. Turkish Online Journal of Educational Technology-TOJET, 13(1), 199-206.

Etemadfar, P., Soozandehfar, S. M. A., \& Namaziandost, E. (2020). An account of EFL learners' listening comprehension and critical thinking in the flipped classroom model. Cogent Education, 7(1), 1835150.

Gharehblagh, N. M., \& Nasri, N. (2020). Developing EFL Elementary Learners' Writing Skills through Mobile-Assisted Language Learning (MALL). Teaching English with Technology, 20(1), 104-121.

Ghorbani, N., \& Ebadi, S. (2020). Exploring learners' grammatical development in mobile assisted language learning. Cogent Education, 7(1), 1704599.

Graham, C. R. (2006). Blended learning systems. The handbook of blended learning: Global perspectives, local designs, 1, 3-21.

Hafifah, G. N., \& Sulistyo, G. H. (2020). Teachers'ıct literacy and ICT integration in ELT in the Indonesian higher education setting. Turkish Online Journal of Distance Education, 21(3), 186198.

Hol, D., \& Aydin, I. (2020). Is Technology in Our Classrooms? EFL Teachers' Beliefs and Engagement with Technology in the Classroom. Journal of Educational Issues, 6(2), 38-58.

Istifci, I. (2017). Perceptions of Turkish EFL students on online language learning platforms and blended language learning. Journal of Education and Learning, 6(1), 113-121.

Iyitoğlu, O., \& Erişen, Y. (2017). Delving into flipping EFL classroom: A mixed method study. European Journal of English Language Teaching.

Korkmaz, S., \& Öz, H. (2021). Using Kahoot to Improve Reading Comprehension of English as a Foreign Language Learners. International Online Journal of Education and Teaching, 8(2), 1138-1150.

Leakey, J., \& Ranchoux, A. (2006). BLINGUA. A blended language learning approach for CALL. Computer assisted language learning, 19(4-5), 357-372.

Littlejohn, A., \& Pegler, C. (2007). Preparing for blended e-learning. Abingdon, UK: Routledge.

Nakayama, M., Mutsuura, K., \& Yamamoto, H. (2016). Student's Reflections on Their Learning and Note-Taking Activities in a Blended Learning Course. Electronic Journal of e-Learning, 14(1), 4353 . 
Oliver, M., \& Trigwell, K. (2005). Can 'blended learning' be redeemed?. E-learning and Digital Media, 2(1), 17-26.

Osifo, A. (2019). Improving Collaboration in Blended Learning Environments through Differentiated Activities and Mobile-Assisted Language Learning Tools. International Association for Development of the Information Society.

Papadima-Sophocleous, S., Giannikas, C. N., \& Kakoulli-Constantinou, E. (2014, August). ICT in EFL: The global effect of new technologies in the language classroom. In Proceedings of the 2014 EUROCALL Conference CALL Design: Principles and Practice (pp. 296-300). Groningen: Research-publishing.net.

Pardede, P. (2020). Secondary School EFL Teachers' Perception of ICT Use in Learning and Teaching: A Case Study in Greater Jakarta. Journal of English Teaching, 6(2), 144-157.

Paudel, P. (2021). Information and Communication Technology in Foreign Language Classes in English: Roles and Practices. International Journal of Technology in Education and Science, 5(1), 37-55.

Rianto, A. (2020). Blended Learning Application in Higher Education: EFL Learners' Perceptions, Problems, and Suggestions. Indonesian Journal of English Language Teaching and Applied Linguistics, 5(1), 55-68.

Samarin, W. J. (1987). Lingua franca. Walter de Gruyter.

Sato, T., Murase, F., \& Burden, T. (2020). An Empirical Study on Vocabulary Recall and Learner Autonomy through Mobile-Assisted Language Learning in Blended Learning Settings. Calico Journal, 37(3).

Sharma, P. (2010). Blended learning. ELT Journal, 64(4), 456-458.

Tran, T. T. T., \& Ma, Q. (2021). Using Formative Assessment in a Blended EFL Listening Course: Student Perceptions of Effectiveness and Challenges. International Journal of Computer-Assisted Language Learning and Teaching (IJCALLT), 11(3), 17-38.

Tucker, C. R. (2012). Blended learning in grades 4-12: Leveraging the power of technology to create student-centered classrooms. California, USA: Corwin.

Wang, C. (2021). Employing blended learning to enhance learners' English conversation: A preliminary study of teaching with Hitutor. Education and Information Technologies, 26(2), 2407-2425.

Wang, N., Chen, J., Tai, M., \& Zhang, J. (2021). Blended learning for Chinese university EFL learners: learning environment and learner perceptions. Computer Assisted Language Learning, 34(3), 297-323.

Wu, W. C. V., Hsieh, J. S. C., \& Yang, J. C. (2017). Creating an online learning community in a flipped classroom to enhance EFL learners' oral proficiency. Journal of Educational Technology \& Society, 2O(2), 142-157. 